INTERNATIONAL JOURNAL OF RESEARCHES IN BIOSCIENCES, AGRICULTURE AND TECHNOLOGY (c) VISHWASHANTI MULTIPURPOSE SOCIETY (Global Peace Multipurpose Society) R. No. MH-659/13(N) www.vmsindia.org

\title{
VITAMIN C OF SOME UNUSUAL LEAFY VEGETABLES
}

\section{Minakshi Mahajan' ${ }^{1}$ and Rajendra Pati12}

\author{
${ }^{1}$ Ferguss on College, Pune \\ 2Amolakchand Mahavidyalaya, Yawatmal \\ Email-minakshi7mahajan@gmail.com
}

Abstract

Unusual vegetables like Boerhaavia diffusa, Chenopodium album, Portulaca oleracea, Tamarindus indica, Oxalis corniculata, osalis latifolia, Bauhinia purpureaand Alternanthera triandra are the sources of nutrients for the body of human be ings. Leafy vegetable s are rich in dietary fibers, iron, calcium and vitamin C. Vitamin C of some of the unusual leafy vegetables was found to be considerably high. They can be included in the diet.

\section{Introduction-}

The term ve ge table includes all foods of vege table origin, but the definitions now exclude ce reals and dried seeds of pulses. Regular use of leafy vegetables supplies many of the most essential health building and protecting substances, such as vitamins and mine rals. Food is a source of essential nutrients require for health promotion and disease prevention. Increases in amount of natural dietary products are the basic necessity of human body for fighting again the diseases. These products produce antioxidants. (Barlow, 1990: Rice- Evans et. al. 1997). Among the various enzymatic and nonenzymatic parameters of antioxidants, vitamin C is one of the important, most powerful antioxidants (Smirnoff, 1996; Arrigoni and de Tullio, 2000; Horemans et. al. 2000b.). Vitamin C de ficiency exacerbates athe rogenes is in animal's models. In order to protect the body from degeneration of diseases, vegetables play an important role (Ogunlesi M., \& et. al. (2010). Vitamin C is naturally synthesized in the body of human being, it is not synthesized endogenou sly and there fore it has to be consumed through leafy vegetables. (LI Y and Schell horn H.E. (2007) Food and Nutrition Board at the Institute of Medicine (IOM) of the National Academies (formerly National Academy of Sciences) recommended dietary intake for Ascorbic acid in the daily diet. (2000).

There are many crops cultivated as vegetables suitable for different seasons and climate. But is appears that the people are not having a full choice for their tastes and requirements or they are not getting these according to their need in the season, and therefor people got diverted for the use of other plant parts of the crops that are found growing as wild plants and some as weeds. ( Bhapkar and Bhore (1961). The weeds like Boerhaavia diffusa, Chenopodium album, Portulaca oleracea, Tamarindus indica, Oxalis corniculata, osalis latifolia, Bauhinia purpureaand Alternanthera triandra were selected for the experiments, are consumed as unusual vegetables (Chauhan, (1989).

\section{Material and methods}

Eight types of leafy vegetables were selected for analysis. These were Boerhaavia diffusa, Chenopodium album, Portulaca oleracea, Tamarindus indica, Oxalis corniculata, osalis latifolia, Bauhinia purpureaand Alternanthera triandra. The plant material neatly washed in tap water.

The analysis of Vitamin C (Ascorbic acid) in all the leafy samples were carried out by Sadasivan and Theymoli Balasubramenan, 1987)

\section{Result and discussion}

Result

\begin{tabular}{|l|l|l|}
\hline $\begin{array}{l}\text { Sr. } \\
\text { No. }\end{array}$ & Name of the plant & $\begin{array}{l}\text { Vitamin C } \\
\text { (Ascorbic } \\
\text { Acid) } \\
\mathrm{mg} / \mathrm{g}\end{array}$ \\
\hline 1 & $\begin{array}{l}\text { Boerhaavia diffusa } \\
\text { Chenopodium album }\end{array}$ & $\begin{array}{l}306.1234 \\
306.1234\end{array}$ \\
\hline 3 & Portulaca olercea & 204.0822 \\
\hline 4 & Tarindus indica & 61.2246 \\
\hline 5 & Oxalis corniculata & 122.4492 \\
\hline 6 & Oxalis latifolia & 122.4492 \\
\hline 7 & Bauhinia purpurea & 102.0410 \\
\hline 8 & $\begin{array}{l}\text { Alternanthera } \\
\text { triandra }\end{array}$ & 40.8164 \\
\hline
\end{tabular}

Among the unusual leafy vege tables, the highest level of vitamin $\mathrm{C}$ was recorded in the leaves of Boerrhavia diffusa and lowest in Alternanthera triandra. Vitamin $\mathrm{C}$ contents of all these plants under study were found to be considerably high so it is advisory to include them in day to day diet. The person who suffers from deficiency of vitamin C. should consume the Boerhaavia diffusa and Chenopodium album leaves as a vegetable in the ir diet. 


\section{References-}

Arrigoni O, De-Tullio MC (2000). The role of ascorbic acid in cell metabolis $\mathrm{m}$ between genes directed functions and unpredictable chemical reactions. J. P1. Physio. 157:481-488.

Balola, O.O. Tugbobo O.S. and Daramola A.S. (2010), Effect of Processing on the Vitamin C Content of Seven Nigerian Green Leafy Ve getables. Advance Journal of Food

Barlow, S. N. (1990). Toxicological aspects of antioxidants used as food additives, Elsevier P. 253.

Bello A. A and Fowoyo P.T.(2014), Effect of heat on the ascorbic acid content of dark green leafy vege tables and citrus fruits. African Journal of Food Scie nce and Technology (ISSN: 2141-5455) Vol. 5(4) pp. 114-118, April.

Bhapkar, D.G. and Bore, D. P. (1961 ): Some Unu sual Vegetables, Poona Agri. Coll. Magazine, Vol. 52, No. 1 and 2,

Chauhan D.V.S., (1989). Ve ge table Production in India.

Horemans N. Foyer CH, Potters, G. Asard H (2000b). Ascorbate function and associated transport systems in plants J. Pl. Physiol. Biochem. 38 : $531-540$.

Institute of Medicine, Food and Nutrition Board (2000). Dietary Reference Intakes for Vitamin C, Vitamin E, Selenium, and Carotenoids Washington, DC: National Academy Press.

Kumar G. V., Kumar A. K., Raghu P.G.R. and Man jappa S. (2013), De te rmination of vitamin C in some fruits and vegetables in Davanage re city, (Karanataka) - India, International Journal Of Pharmacy \& Life Sciences, ISSN: 0976-7126
LI Y, and Schellhorn H.E. (200). New developments and novel therapeutic perspectives for Vitamin C. J Nutr., 137:217-84.

NORTHERN NIGERI Journal of Global Biosciences ISSN 2320-1355 Volume 4, Special Issue 1, 2015, pp. 1867-1870

Ogunlesi M., Okiei W., Azeez L., Obakachi V., Osunsanmi M., and Nkenchor G. (2010): Vitamin C contents of Tropical vegetables and foods Determined by Voltammetric and Titrimetric me thods and their Re levance to the med icinal use of the plants. International Journal of Ele ctro chemical Science. 5 (2010) 105-115.

Randhawa, M.S. (1966). What Nutition vegetables contain, Indian Horticulture, Vol. X (2), pp. 5-6.

Rice-Evans CA, Miller NJ, Pagnanga G (1997). Antioxidant properties of phe nolic compounds. Trends Plant Sci. 2: 152-159.

Sadasivan, S and Theymoli Balasubraminan 1987. In practical manual in Biochemistry Tamil Nadu Agricultural University Coimbatore P14.

Sani Abdulrazak, Yusuf Abdulraheem Oniwape le, Dennis Otie and Yusuf Ishola

Science and Technology 2(6): 303-305.

SELECTED FRUITS AND VEGETABLES COMMONLY CONSUMED IN

Smirnoff N (2000). As corbic acid: me tabolism and functions of a multifaceted molecule. Curr. opinion Pl, Biol. 3: 229-235.

Sulyman COMPARATIVE DETERMINATION OF ASCORBIC ACID IN SOME 